\title{
GROWTH AND HEALTH OF BELGIAN CHILDREN * DURING AND AFTER THE GERMAN OCCUPATION (1940-1944)
}

\author{
BY
}

\author{
RICHARD W. B. ELLIS, O.B.E., M.D., F.R.C.P. \\ Late Wing-Commander, R.A.F.V.R., and O.C. Medical Division, a R.A.F. General Hospital, \\ B.L.A.; Physician in charge of the Children's Department, Guy's Hospital, London
}

The following study was undertaken in the winter of 1944-5, three months after the liberation of Belgium, in order to determine if permanent illeffects of the occupation were manifest in children reared during the war; to review the measures that had been taken to protect children against the severe deprivations from which the country as a whole had suffered; and to assess how far these measures had been successful. Observations were largely confined to the Brussels area, which, though suffering less from aerial bombardment than some other Belgian cities, had had to face the common problems of evacuation, closure of schools, shortage of fuel, and rigid control by the occupying military government in addition to totally inadequate civilian rations. Clinical examinations of children were carried out in infant welfare centres, crèches, orphanages, school and hospital clinics, and in private homes; by courtesy of school medical authorities and the Ministry of Public Health, access was obtained to school medical records and examinations of adolescents in state employment; and a detailed study was made of a typical workingclass family with three children reared during the war years.

Official rations and the black market. Any figures relating to rations received by the civilian population of Belgium during the war years must be accepted with the utmost reserve. The so-called ' official' rations were seldom if ever available in full, and the food-income of any individual family would vary according to the reserves available, the number of children in the household, the capacity to buy on the black market, the possession of a garden or relatives in the country, medical certification, and other indeterminable factors. Bastenie and his co-workers (1944) have divided the period under review as follows:

1. The serious period when food-supplies were extremely reduced (1941-2).

2. The period when food-supplies were 'corrected' by distribution of herrings, by an increased supply of potatoes, and finally by organization of the black market.

* Part of this study was included in a paper read before the Children's Section of the Royal Society of Medicine in February,
1945 (Ellis, 1945).

\section{The present time (November, 1944).}

They give the following figures comparing the caloric requirements for each age-group with those provided by the basic rations and official supplements in 1941-2:

\begin{tabular}{c|c|c}
\hline $\begin{array}{c}\text { Age } \\
\text { (years) }\end{array}$ & $\begin{array}{c}\text { Daily caloric } \\
\text { requirements }\end{array}$ & $\begin{array}{c}\text { Calories supplied by } \\
\text { official rations }\end{array}$ \\
\cline { 1 - 2 } $0-3$ & 970 & 1,800 \\
$3-6$ & 1,500 & 1,500 \\
$6-14$ & 2,200 & 1,450 \\
$14-18$ & 2,700 & 1,380 \\
18 and over & 2,600 & 1,230 \\
Pregnant & 2,600 & 2,000 (1941 to Feb. 1942) \\
woman & - & 2,000 to 2,240 (from Feb. \\
& & 1942) \\
\hline
\end{tabular}

These figures illustrate forcibly the principle that was adopted from the beginning of the occupation in Belgium, viz. that the younger children should be the last to suffer. They also show the price paid by adolescents and adults, and suggest that a family in which the children were all under six years of age would be much better off than one in which the children were older. In addition, the youngest children were less deprived of fat, first-class protein, and calcium, since the whole of the available milksupply was allocated to children and invalids. (The daily ration of milk was $\frac{3}{4}$ litre to the age of three years, $\frac{1}{2}$ litre from three to six, and $\frac{1}{4}$ litre from six to fourteen, although this was frequently unobtainable for the older children.) Gregoire (1942) estimated that between fourteen and eighteen years of age, adolescents were receiving only 31 per cent. of their minimum calcium requirements $(0.25 \mathrm{gm}$. as compared with $0.8 \mathrm{gm}$.); it is perhaps significant in this connexion that Henry (1945) noted a striking increase in the number of ununited fractures occurring in the department of children's surgery of Brussels University during the war years.

As would be expected from the agricultural economy of Belgium (Colard, 1945), which is largely devoted to the growing of vegetables and the production of beet sugar, the qualitative deficiencies in the diet lay principally in the lack of meat and butter. Potatoes formed the staple 
article of diet, since the quality of the bread in 1941-2 became so bad that it was almost uneatable; one child described it as 'comme du mastic et on pouvait en faire de boule et le coller au mur comme on le ferait avec de pâte.'

No consideration of war-time rationing in Belgium would be complete without mention of the black market. It is unfortunate that this term, with its implication of private profit at the expense of the community, has been applied to what was essentially a rough-and-ready method of survival of the civilians at the expense of the invader. Undoubtedly some unscrupulous individuals made large profits out of the system, which was crude and uneconomical, but at the same time it did save the great majority of the population from starvation. Reduced to its simplest terms, it consisted in town-dwellers going into the country and buying as much farm-produce as they could carry back. The farmers sold to the civilians at reasonable prices, thus preventing their goods falling into the hands of the Germans and incidentally saving the problem of transport. The townsman then kept what he required and sold the remainder at two to five times what he had paid for it. On this he was then able to buy in the town other necessities which had been similarly acquired. Individual enterprise was usually limited by what could be carried, and by the fact that if large quantities of goods were brought back in a public vehicle they were liable to confiscation. Unfortunately the practice, once acquired, persisted after the liberation, when it was found that for some months the official rations showed little if any improvement except in the quality of the bread.

Vital statistics. The birth rate in Belgium showed a fall during the war until 1943, when it again approximated to the pre-war level. The infantile mortality (deaths under one year) showed a slight rise until 1943, when it fell below the prewar level. The total infantile mortality for 1944 is not yet available, and the figure given (to October) probably represents a slightly lower percentage than over the full year. The corresponding figures for Holland are given when available.

It has not been possible to obtain the death rates for older children during the war years but I understand that the deaths from tuberculosis rose during the period of most restricted rationing (in 1941-2) when the total deaths from this cause per 100,000 of the population rose from the pre-war figure of $67 \cdot 5$ to $98 \cdot 3$.
General health. There were no major epidemics amongst children during the war, and although there was some increase in the incidence of diphtheria, the disease does not appear to have been exceptionally severe. Owing doubtless to the extreme shortage of soap and fuel, teachers in the poorer schools all commented on the increase in scabies, impetigo and pediculosis during the war. Henry (1945) noted a striking increase in the number of cases of osteomyelitis in children admitted to his service in Brussels, which he attributed as much to skin sepsis as to malnutrition. Postural defects were also seen much more frequently during the war years, although here the relationship between defective muscle tone and malnutrition was closer. Again in the poorer schools, apathy and intellectual retardation were noted during the period of severest deprivation (1941-2). There appears to have been a definite increase in enuresis, though obviously the admission of children to holiday-homes and colonies or evacuation to foster-parents would tend to bring the condition to light more than in normal times. It seems probable that an ill-balanced diet, lacking in first-class protein, may have been a factor in the etiology, but where factors having a psychological effect, such as air-raids and broken homes, are present, it is impossible to speak with certainty. Amongst the younger children admitted to hospital, a large proportion were found to show a mild degree of hypochromic anaemia.

Famine oedema was of extreme rarity amongst children, less than five cases having been seen in the university clinic in Brussels during a period when some 400 were observed in adults in the same hospital.

DEFICIENCY DISEASES. With the possible exception of skin sepsis, and follicular hyperkeratosis (of which the interpretation is complicated, and which will be discussed in another communication), no gross clinical evidence of vitamin A deficiency was reported amongst children during the occupation, or observed amongst those examined in 1944-5. As carrots are grown in large quantities in Belgium, it is probable that most households received a more or less liberal supply of vitamin A at least during certain seasons throughout the war years, in spite of the deprivation of fat.

Admissions to the children's service, Brussels University, showed no increase in infantile scurvy, and no case of scurvy was seen in an older child (Dubois, 1945); paediatricians were agreed that they had seen no more cases in private practice than

\begin{tabular}{|c|c|c|c|c|c|c|}
\hline & 1939 & 1940 & 1941 & 1942 & 1943 & $\begin{array}{c}1944 \\
\text { (to October) }\end{array}$ \\
\hline Births per 1,000 population $\ldots\}$ Belgium & $\begin{array}{l}15 \cdot 0 \\
20 \cdot 6\end{array}$ & $\begin{array}{l}13 \cdot 3 \\
20 \cdot 8\end{array}$ & $\begin{array}{l}11 \cdot 9 \\
20 \cdot 3\end{array}$ & $\begin{array}{l}12 \cdot 8 \\
20 \cdot 9\end{array}$ & $\frac{14 \cdot 6}{-}$ & 二 \\
\hline Deaths per 100 live births $\ldots\} \begin{array}{l}\text { Belgium } \\
\text { Holland }\end{array}$ & $\begin{array}{l}7 \cdot 3 \\
3 \cdot 4\end{array}$ & $\begin{array}{l}8 \cdot 5 \\
3 \cdot 9\end{array}$ & $\begin{array}{l}8 \cdot 4 \\
4 \cdot 3\end{array}$ & $\begin{array}{l}7 \cdot 8 \\
4 \cdot 0\end{array}$ & $\frac{6 \cdot 7}{-}$ & $7 \cdot 8$ \\
\hline $\begin{array}{ccccc}\text { Illegitimate births per } 100 & \text { live } & \\
\text { births } . & \ldots & \ldots & \ldots & \text { Belgium }\end{array}$ & $3 \cdot 4$ & $3 \cdot 1$ & $3 \cdot 1$ & $2 \cdot 3$ & $2 \cdot 6$ & - \\
\hline
\end{tabular}


in normal times. Pellagra in childhood was not observed.

With regard to the question of a war-time increase in rickets in Belgium, it is impossible to speak with certainty in the absence of pre-war figures. Judging by the large number of minor thoracic deformities of rachitic type which $I$ have seen in older children in Belgium (e.g. in 42 per cent. of a group of ' normal' working-class schoolboys aged ten to twelve) I feel no doubt that rickets at least of mild degree was common before the war. The impression gained, however, from the children's orthopaedic clinic of Brussels University and from crèches in the poorer parts of the city was that there had been a definite increase in the severer manifestations, particularly in genu valgum and varum. The photograph shown below, taken in 1942, shows a group of toddlers at the Sanatorium des Petites Abeilles in Brussels, an institution devoted to the care of malnourished and abandoned children (fig. 1). Whilst the inmates represent a selected group, over 70 per cent. of the infants showed more or less severe stigmata of rickets on admission and the applications for admission had more than doubled since 1939.

DeBILITY. Whilst the classification of children as ' debilitated' had a certain practical value during the war in forming a basis for recommendations on medical grounds for extra rations or admission to children's colonies, the term is obviously too illdefined to have much scientific value, and no attempt will be made here to give figures for the war years. Jacquemijns (1941) carried out an investigation on some 15,000 children from three to fourteen years of age in which he reached some general conclusions pointing to a deterioration in physical condition in January, 1941, as compared with May, 1940, but this preceded the severest period of restriction; he concluded at that time that adolescents were suffering considerably more than children under fourteen years of age. An investigation begun in January, 1941, and carried on to July, 1942, by the Association des caisses d'allocations familiales (1942) was suppressed by the German authorities. It served to show, however, a deterioration during the first semester of
1942 as compared with 1941 , and indicated that the deterioration was much more marked in children living in large industrial areas than in those living in the country.

Children's services. It would be impossible to speak too highly of the work of the various organizations concerned with the welfare of children during the occupation, and it is undoubtedly due to their devotion and foresight, and to an enlightened public policy, that a whole generation of Belgian children has suffered relatively little permanent ill-effect from a period of prolonged national malnutrition. Some of the principal means by which the health and nutrition of children were safeguarded are as follows:

1. The national milk-supply was allocated to children on an age basis (see p. 97).

2. Supplementary rations of sugar, flour, vitamins and calcium were distributed through welfare clinics.

3. Children requiring additional food or institutional treatment were selected by school medical examinations. (The records of these were kept in a separate dossier for each child, and included height and weight records.)

4. Debilitated children could be admitted to children's colonies (preference being given to those when a parent was a prisoner or had been transferred to Germany for forced labour), or to openair schools, where supplementary rations were available.

5. Free meals could be prescribed in selected cases at various canteens (many of these being run on a voluntary basis and some by neutral relief organizations, e.g. Swedish).

6. Evacuation was arranged to peasant homes or to colonies supported by local peasant communities. Switzerland has also given hospitality to a considerable number of Belgian children.

7. The existing services, e.g. welfare clinics, crèches, children's colonies, health-visiting, were expanded throughout the country, every measure was adopted to encourage breast-feeding and mothercraft training, and a lactarium was established in Brussels where nursing mothers with excess breastmilk could sell this at $30 \mathrm{fr}$. a litre and obtain extra rations, the milk then being available on medical prescription for necessitous cases.

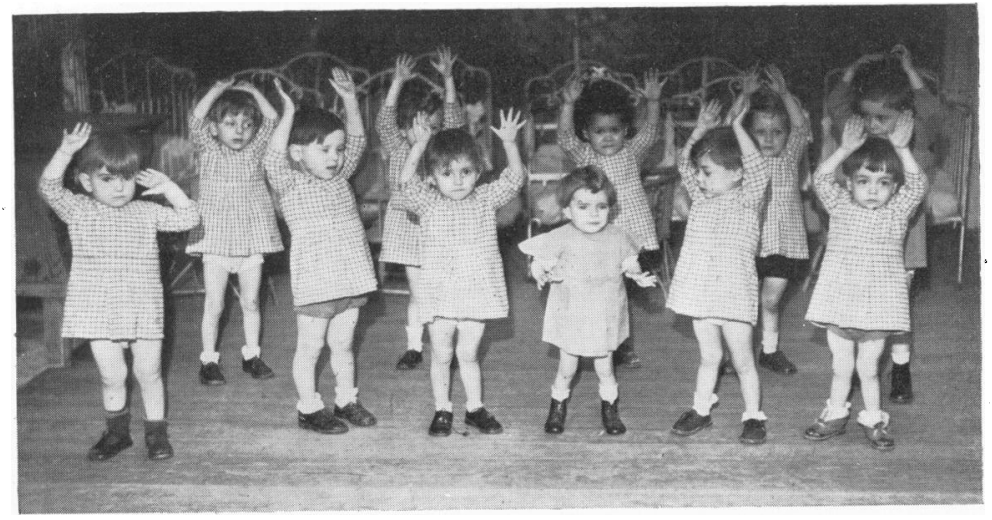

Fig. 1.-Group of infants in Sanatorium des Petites Abeilles, Brussels, showing genu valgum. 
Whilst a great many organizations shared in the common effort, particular mention must be made of the Oeuvre Nationale de l'Enfance, the Secours d'Hiver (now the Comité National de Secours), and the Croix Rouge, all of which worked in cooperation. The number of infants attending welfare clinics rose from 105,548 in 1939 to 168,847 in 1943. District nurses were available for domiciliary visits to infants in 1,547 villages in 1943 as compared with 449 in 1939, whilst the number of residential children's colonies was increased from 54 in 1939 to 483 in 1943.

\section{Study of a working-class urban family}

The following description is given in some detail, as it illustrates how two working-class parents were able to rear three children during the occupation, and the condition of the children in Feburary, 1945. The family was selected at random before either parents or children had been seen, and appears to have been neither exceptionally fortunate nor unfortunate during the period under review.

The family D. consists of the father, aged 38, who is Walloon and French-speaking and the mother, aged 31, who is Flemish and Frenchspeaking; two boys (Joseph, aged 13, and Marcel, aged 11 $\frac{1}{2}$ ); and a girl (Eliane, aged 3 years 4 months). They live in an outlying commune in the Brussels area in a two-storey attached house consisting of four rooms (kitchen-living room, two bedrooms, and a store-room) for which they pay $130 \mathrm{fr}$. a month; there is no gas or electricity, and water is obtained from an outside tap serving six houses. There is a yard but no garden. The house always looks and smells clean and is plainly but adequately furnished. During January, 1945, it was extremely cold except in the evening when there was just sufficient fire (of coke and wood chips) in the stove to boil a kettle, and a carbide lamp. The father is an unskilled labourer (mechanic's mate) who suffers from asthma and emphysema. He left Belgium at the time of the invasion, in 1940, bicycling to Toulouse, whence he returned four months later after the occupation of France. He was out of work for six weeks in 1943 with pneumonia and for eighteen weeks in 1944-5 with asthma and bronchitis. When he is working he earns $5 \mathrm{fr} .60 \mathrm{c}$. an hour and works forty-eight hours a week. For seven weeks when he was sick the mother was working three hours a day in domestic service at $8 \mathrm{fr}$. an hour, gaining $144 \mathrm{fr}$. a week. From 1941 until the time of the liberation, one or more members of the family would go out of town by tram two or three times a week to buy farm produce, keeping what they required and selling the remainder. On the first occasion, all their purchases costing $500 \mathrm{fr}$. were confiscated. This did not occur again. When the mother is working, the youngest child is looked after during the day by the grandmother, whose three sons were deported for forced labour in Germany in 1941. Neither of the boys qualified for free meals at a Swedish canteen during the war, as they were not regarded as debilitated.

JoSEPH D., aged 13 years, was breast-fed for eight months; treated for genu varum at age of two, with complete recovery. He was in bed for eight weeks in 1944 owing to a wound of right thigh, but apart from this has missed no school on account of illness. Height, $56 \frac{3}{4}$ in. $(144 \mathrm{~cm}$.); weight, $83 \frac{1}{2} \mathrm{lb}$. (38 $\mathrm{kgm}$.). (Both within normal average for age.) Good colour and musculature but slender build. Teeth all good condition and well calcified. Skin: small area of follicular hyperkeratosis posterior aspect of both upper arms; linear scar right thigh; otherwise normal. Slight deformity of sternum of rachitic type. Physical examination otherwise essentially normal. Secondary sexual characters not yet appearing. Haemoglobin 98 per cent. X-ray of hand: normal calcification and development for age; centre for pisiform present. Mental condition: alert and cheerful; no nervous traits. School reports: average.

MARCEL D., aged 11 years 6 months, was breastfed for nine months. He was treated for scoliosis at the age of five, and was away from school for three weeks in 1943 with sore throat; otherwise he has had no illnesses. Height, 53 in. $(134.6 \mathrm{~cm}$.); weight, $76 \frac{1}{2} \mathrm{lb}$. $(34 \cdot 8 \mathrm{kgm}$.). (Both within normal average for age.) Good colour; stockier build than elder brother. Teeth all good; twelve-year molars erupted. Skin normal except for septic abrasion of ankle caused by clogs. Slight deformity of sternum of rachitic type. Physical examination otherwise normal. Haemoglobin 95 per cent. X-ray hand: normal calcification and development for age. Mental condition: alert and cheerful; school reports good. Suffered from enuresis to age of five years when he was circumcised; free from enuresis since age of six; no nervous traits now.

Both boys were in a children's colony from October, 1941, to March, 1942, and in holiday camps (under the Oeuvre Nationale de l'Enfance) for six weeks in 1942 and one month in 1943. During these times the parents paid 3 fr. a day each for their maintenance and they received double rations. They received schooling during these periods. Their school in Brussels was closed for a month owing to shortage of coal in the winter of 1943, again from June to September, 1944, owing to bombardments, and again in the winter of $1944-5$ owing to lack of coal and flying bombs. (In February, 1945, they had received only eight weeks' regular schooling since June, 1944.) Both received vitamin $A$ and $D$ and calcium tablets whilst attending school but not when the school was closed. During the holidays, both boys help in the house, make periodic forays into the country to operate the black market, collect wood, distract the airmen in the motor transport yard, and attend scout meetings and excursions. Both are keen readers (literature-Buffalo Bill, Jack London, and Le Livre de la Jungle); and go to the cinema once a week (favourite films-Tarzan l'Intrepide, Actualités, and $\mathrm{Au}$ Revoir, Monsieur Chips).

EliANE, D., aged 3 years 4 months, was breastfed for nine months. Stood at 7 months, walked at $10 \frac{1}{2}$ months. Has attended welfare clinic regularly and receives vitamized oil. She has had no illnesses. Height, 361 in. $(92 \cdot 2 \mathrm{~cm}$.); weight, $30 \mathrm{lb} .12 \mathrm{oz}$. (14 kgm.). (Both within normal average for age.) Good colour, extremely active, muscle tone good. Slight flaring of lower ribs; moderate degree of genu valgum present; no beading of ribs; skull normal. Twenty teeth present, well calcified. Skin normal except for 
septic lesion left hand. Haemoglobin 100 per cent. X-ray hand and wrist: Os magnum, unciform and cuneiform present; centres for trapezoid and semilunar appearing. (Development advanced for age.) No radiological evidence of active rickets; slightly increased density of growing end of radius; no lines of arrested development. Mental state: advanced for age. Speaks both French and Flemish clearly, without mixing the two languages. Favourite occupation: dancing. Favourite drink: beer.

Clothing of each child consisted of a best suit in good repair but of poor quality material, and an everyday suit cut down from their parents'. None of the children had woollen underclothes or overcoat and during the bitter weather in January, 1945, all three suffered considerably from the cold, the price of warmer clothing being prohibitive. Bedding, however, was adequate.

Cleanliness both of the children and their linen was surprising. (They were purposely examined on several occasions without previous preparation.) The mother commented, however, that 'since the war every scratch seemed to fester.'

Weekly budget. Madame D. kindly undertook to set down every item purchased for the household for the first week in February, 1945. Certain lessfrequently recurring items have been included as a pro rata amount, e.g. potatoes, which had been purchased in bulk some time previously. Shoe repairs are not included, as the use of clogs rendered the amount negligible. Cinemas for the boys also generally represent tips or payment for an odd errand, and are not included. (Table 1.)

In order to help balance this formidable budget, the sugar ration (1 $\mathrm{kgm}$. $250 \mathrm{gm}$.) bought for $10 \mathrm{fr}$. 65 c. was sold for 90 fr. (thus paying for the $250 \mathrm{gm}$. bacon bought on the black market), and the milk coupons for which no milk could be obtained from the family's dealer were sold for $150 \mathrm{fr}$. This leaves a deficit of $123 \mathrm{fr}$. on the week's trading, to be made good from savings (of which $100 \mathrm{fr} .75 \mathrm{c}$. is represented by coke, soap and potatoes previously purchased) or by operation of the black market. (It had not been possible for the boys to bring back farm produce during the week under review, owing to the weather and state of the roads.)

It will be seen that the whole of the week's wages are expended on rent, soap, fuel, and light, although the fuel was insufficient to warm one room for more than a few hours each day, and light consisted of a single lamp lighted for four hours each evening. The most interesting feature of the expenditure on food is the way in which the mother has chosen to supplement the official rations. The largest item goes on fresh vegetables, which are unrationed. (The figure of $117 \mathrm{fr} .50 \mathrm{c}$. is, however, rather misleading, since vegetables were exceptionally expensive during early February owing to the severe frost throughout January, and this partly accounts for the deficit on the total budget.) The next item is even more significant, since faced with a family diet which is rich in carbohydrate and vitamins A, B and $\mathrm{C}$ but dangerously low in fat and first-class protein, the mother has on her own initiative sacrificed the whole of the week's sugar ration in order to buy $250 \mathrm{gm}$. bacon at nine times the official price.

Comment. Whilst there are undoubtedly a great many Belgian families less fortunate than the family D., the study of this family does show that an unskilled labourer and his wife have been able to rear three healthy children during the occupation. The term healthy is applied to the children in its widest sense and refers equally to their physical, intellectual, and emotional make-up. All three are cheerful, normally intelligent, and extremely active. Doubtless they would weigh more if they had had more to eat and would be more advanced scholastically if their schools had not been closed for four months out of six. But with the possible exception of the youngest child's genu valgum (which is correctable) there is no evidence that they will carry any serious ill-effects of the war years into later life.

The Oeuvre Nationale de l'Enfance has played an important part in the rearing of all three children, placing the two boys in a children's colony in 1941 and twice subsequently in holiday homes. The

TABLE 1

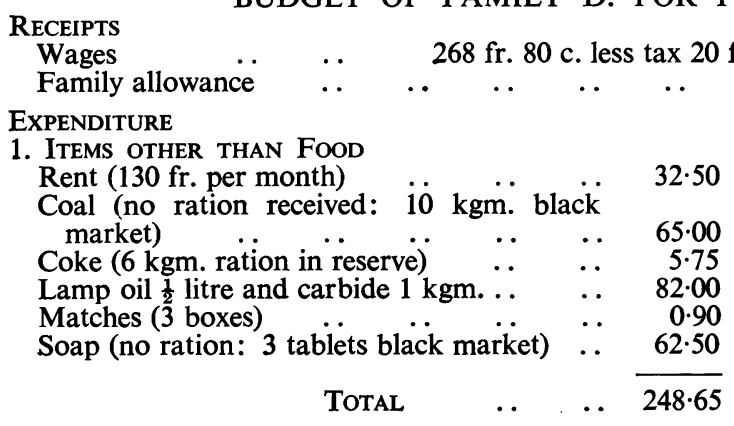

2. FooD

Bread (ration) $12 \mathrm{kgm} .250 \mathrm{gm}$.
Potatoes (reserve at official price $\ddot{1} \cdot 30 \mathrm{fr}$.)

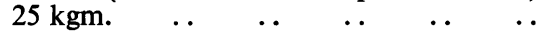

Carrots $1 \frac{1}{2} \mathrm{kgm}$. , chicory $1 \frac{1}{2} \mathrm{kgm} .$. , onions $3 \mathrm{kgm} ., 1$ cauliflower .. .. ..

Dried peas and beans (ration) $325 \mathrm{gm}$. $\quad \ldots$

$\begin{array}{lllll}\text { Margarine (ration) } 500 \mathrm{gm} . & . & \ldots & \ldots & 9.00\end{array}$

Tinned meat and veg. (approx. $300 \mathrm{gm}$. meat) (ration)

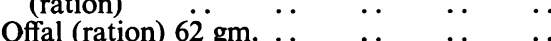

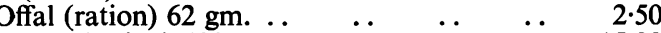

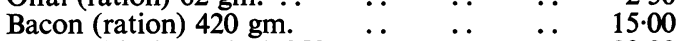

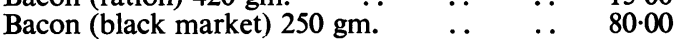

$\begin{array}{llll}\text { Milk } 3 \text { litres ( }\left(\frac{3}{8} \text { official ration) }\right. & \ldots & \ldots & 9.00\end{array}$

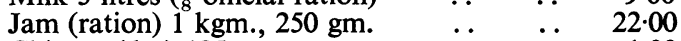

$\begin{array}{lllll}\text { Chicory (dry) } 125 \text { gm. } & . & \ldots & . & 1.00\end{array}$

'Malt' (coffee-substitute: ration) $125 \mathrm{gm}$. $\quad 1.25$

'Malt' (black market) $100 \mathrm{gm} . \quad$.. $\quad . . \quad 6.00$

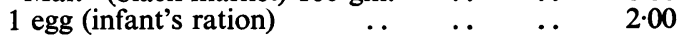

TOTAL $\quad$.. $\quad \ldots \overline{389 \cdot 50}$ 
youngest child has been supervised from birth at a Welfare Centre where she has received supplementary vitamins and sugar. (It should also be noted that until January, 1945, the three children had received their full milk ration-twenty-four litres a month for the baby up to the age of three, and sixteen litres a month subsequently; the ration for the older children has been eight litres a month each.)

The family history also illustrates the method by which the urban population kept alive by the clandestine market during the occupation, and the unfortunate aftermath, viz. that after the danger of local produce being requisitioned for export had ceased with the liberation, the black market was so firmly entrenched that it was still inevitable to buy on it and, in the absence of capital, to continue to operate it. A comparison of the official and black market prices in Brussels in February, 1945, is given below:

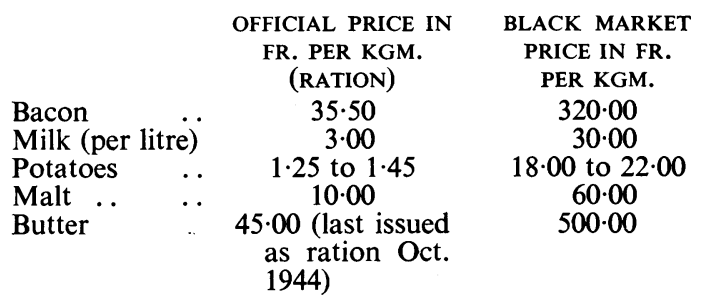

With the improvement in the official rations since this time and stricter control, the hold of the black market in Belgium has been very much reduced.

\section{Growth and development}

Weight of the newborn. Snoeck (1942) has correlated the average gain in weight during pregnancy in 1938-9 and in 1940-1 with the average weight of the newborn in the same periods, classifying his cases as primiparae, secundiparae, tertiparae, and multiparae. Whereas the average gain in weight during pregnancy of primiparae was $7.7 \mathrm{kgm}$. in 1938-9 and only $4.9 \mathrm{kgm}$. in $1940-1$, the average weight of firstborn infants was identical $(3.25 \mathrm{kgm}$.) in both periods. The average weights of secondborn, third, and subsequent infants were respectively 200 gm., 70 gm., and 90 gm. less in 1940-1 than in $1938-9$, but the lowest average weight was $3 \cdot 24 \mathrm{kgm}$. Lust (1942) studied the average weights of the newborn in three large maternity services for each month during 1939, 1940, and the first four or six months of 1941 . His cases were classified as male and female but not according to place in family. His figures suggest that the average weights might vary as much by month and sex as the differences observed by Snoeck. It seems reasonable to conclude that while the pregnant woman was more or less severely affected by the dietetic restrictions in $1940-1$, it is doubtful if the average weight of the newborn was significantly reduced at this time. Garot's figures (1945), obtained in industrial areas for all the war years, confirm this general impression, although there appears to have been a diminution in the number of large babies (weighing more than 4 kgm.) born during the war years as compared with pre-war babies.

Height and weight of schoolchildren. Since the effects of the war diet would be likely to be well presented in an urban working-class community, the commune of Anderlecht was selected for special study. This is an almost exclusively working-class district in the greater Brussels area, and has the advantage of having an excellent school medical service, where examinations are carried out at a central clinic; measurements of height and weight are made by trained personnel under standard conditions with apparatus that is checked regularly. Heights and weights are recorded to the nearest centimetre and half-kgm. respectively, boys being weighed in shorts and girls in knickers. Unfortunately, owing to war conditions, it was impossible to obtain sufficient records to compile curves of the immediate pre-war average heights and weights for each age group, but by random sampling of the 1938-9 records, taking thirty boys and thirty girls for the four age groups seven to eight, nine to ten, eleven to twelve and thirteen to fourteen years, it was found that in every instance the figures were above those compiled for 1944 (see below) and also the standard normals for Belgian schoolchildren published in 1934 by the Ministère de l'Instruction Publique. (These latter, though published in 1934, were compiled some time previously, following a period of severe economic depression in 1928, and were generally recognized as being too low in the later thirties. Thus in one of the poorest-class schools in Etterbeek, an urban commune, 71 per cent. of 1,665 children in 1940 were more than $2 \mathrm{kgm}$. above the 1934 average weight for age.) The figures for the 1938-9 samples are shown below, compared with the corresponding 1944 and 1934 figures:

TABLE 2

\begin{tabular}{|c|c|c|c|c|c|c|}
\hline \multirow{2}{*}{$\begin{array}{c}\text { AGE } \\
\text { (years) }\end{array}$} & \multicolumn{3}{|c|}{ HEIGHT $(\mathrm{cm})}$. & \multicolumn{3}{|c|}{ WEIGHT (kgm.) } \\
\hline & $\begin{array}{l}\text { 1938-9 } \\
\text { (sample) }\end{array}$ & 1944 & 1934 & $\begin{array}{c}1938-9 \\
\text { (sample) }\end{array}$ & 1944 & 1934 \\
\hline & \multicolumn{6}{|c|}{ BOYS } \\
\hline $\begin{array}{r}7-8 \\
9-10 \\
11-12 \\
13-14\end{array}$ & $\begin{array}{l}125 \cdot 0 \\
132 \cdot 1 \\
142 \cdot 8 \\
151 \cdot 0\end{array}$ & $\begin{array}{l}121 \cdot 1 \\
131 \cdot 0 \\
139 \cdot 0 \\
147 \cdot 7\end{array}$ & \begin{tabular}{|l}
$117 \cdot 6$ \\
$127 \cdot 7$ \\
$136 \cdot 7$ \\
$145 \cdot 5$
\end{tabular} & $\begin{array}{l}24 \cdot 2 \\
27 \cdot 3 \\
34 \cdot 2 \\
41 \cdot 0\end{array}$ & $\begin{array}{l}22 \cdot 2 \\
26 \cdot 8 \\
32 \cdot 1 \\
38 \cdot 8\end{array}$ & $\begin{array}{l}22 \cdot 0 \\
25 \cdot 6 \\
31 \cdot 1 \\
36 \cdot 4\end{array}$ \\
\hline & \multicolumn{6}{|c|}{ GIRLS } \\
\hline $\begin{array}{r}7-8 \\
9-10 \\
11-12 \\
13-14\end{array}$ & $\begin{array}{l}122 \cdot 2 \\
130 \cdot 0 \\
144 \cdot 0 \\
151 \cdot 0\end{array}$ & \begin{tabular}{|}
$120 \cdot 6$ \\
$128 \cdot 4$ \\
$138 \cdot 0$ \\
$149 \cdot 9$
\end{tabular} & \begin{tabular}{|l}
116.8 \\
126.6 \\
136.5 \\
148.7
\end{tabular} & $\begin{array}{l}23 \cdot 8 \\
26 \cdot 4 \\
36 \cdot 0 \\
44 \cdot 0\end{array}$ & $\begin{array}{l}21 \cdot 7 \\
25 \cdot 2 \\
31 \cdot 1 \\
41 \cdot 7\end{array}$ & $\begin{array}{l}21 \cdot 4 \\
25 \cdot 1 \\
30 \cdot 4 \\
39 \cdot 3\end{array}$ \\
\hline
\end{tabular}

Owing to the inherent fallacies of random sampling (which were unavoidable in this instance, although as far as they could be cross-checked the samples appeared to be representative), the sample figures cannot be taken as more than a rough guide. It is considered significant, however, that they are in every instance higher than the 1944 figures, and can be taken as indicating that working-class schoolchildren in the Anderlecht commune show an average diminution of both height and weight in 1944 as compared with 1938-9 of a significant but not severe degree.

Comparison of height and weight curves of children aged six to sixteen for the years 1942, 1943 and 1944. Complete records being available of height 
and weight of all Anderlecht schoolchildren examined from September, 1942 (following the severest period of rationing) to the end of December, 1944, it was decided to construct curves showing the average height and weight of all boys and girls examined during October, November and December of each of these years. Only mentally defective children were deliberately excluded. Whilst it was impossible to allow for absence from illness, this was found to be much less than might be expected during the periods concerned, owing to a good followup system and the fact that the school clinic was the channel for obtaining supplementary rations in necessitous cases. Children were divided into sex and age groups $(6+$ to $7,7+$ to 8 , up to $15+$ to 16$)$; there were a considerable number of children under six and a smaller number over sixteen who were not included in the analysis, and it was found that the average age of each group fell within one month of the half-year. The ages are therefore shown graphically as $7 \frac{1}{2}, 8 \frac{1}{2}$, to $15 \frac{1}{2}$. Table 3 includes the number of children on which the averages are based.

For comparison and clarity (since the differences observed between the years 1942, 1943 and 1944 are comparatively small) each curve has been plotted against the corresponding 1934 figures (fig. 2 and 3). As mentioned above, the 1934 figures are almost certainly lower than the immediate pre-war figures for Anderlecht children, and are used simply as a standard comparison for each of the years under review. Age-grouping in the 1934 curves was done by semesters and not by years (fig. 2 to 13).

Comment. Except for certain differences in the case of the elder girls, which are discussed below, the curves for the two sexes show the same general characters and can be considered together. In
1942 , the weights of children from $6 \frac{1}{2}$ to $10 \frac{1}{2}$ correspond closely with the 1934 weights; at $11 \frac{1}{2}$ the girls fall above and the boys below the 1934 weights; and after $13 \frac{1}{2}$ both boys and girls fall consistently below. In 1943, the curves correspond closely throughout to those of 1934, though the weights even of the younger children are slightly higher than in 1942. In 1944, the weights of both boys and girls are almost consistently above those of 1934 . Thus the weights were the lowest in 1942 (as would be expected from the severity of the rationing at this time), girls over $13 \frac{1}{2}$ being most affected, and showed a slight but consistent improvement in 1943 and 1944.

The heights, except in the case of the oldest girls, are consistently above the 1934 figures, the most substantial difference being seen in the boys in 1944 .

It appears, therefore, that working-class children living at home have shown a gradual improvement in weight from 1942 to 1944 , and that their height (with the possible exception of those reaching the normal age of puberty during the war) has been little affected. Their average heights and weights were slightly higher in the autumn of 1944 than those recorded for Belgian schoolchildren in 1934 following a period of economic depression.

Growth of children in a residential school. From visits to a number of residential schools, orphanages, and children's colonies, it was obvious that conditions varied as much or more than in workingclass homes. In some instances there were farms or large gardens attached, which had supplemented the rations throughout the war. In others, under the supervision of the Oeuvre Nationale de l'Enfance

TABLE 3

HEIGHT AND WEIGHT

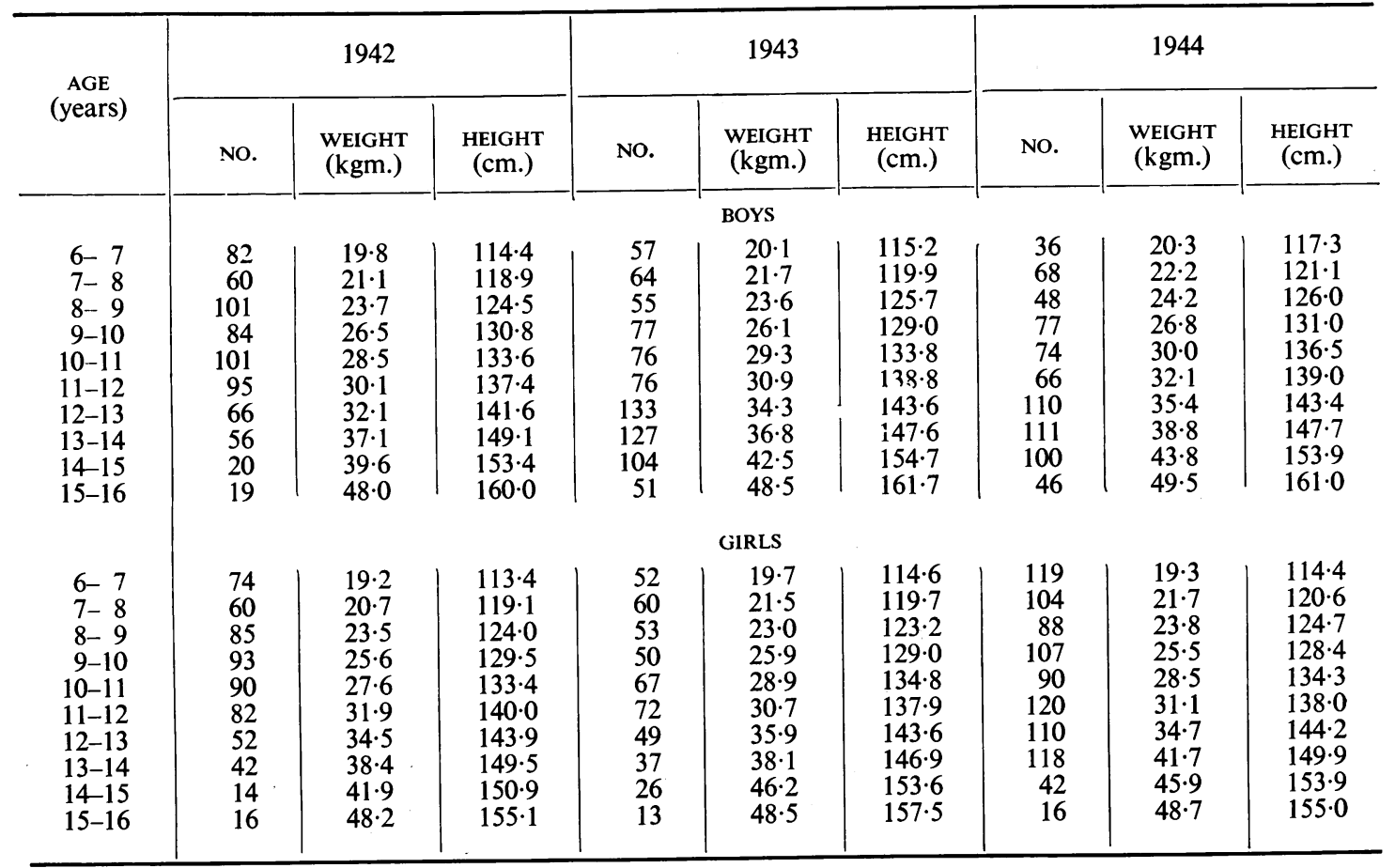



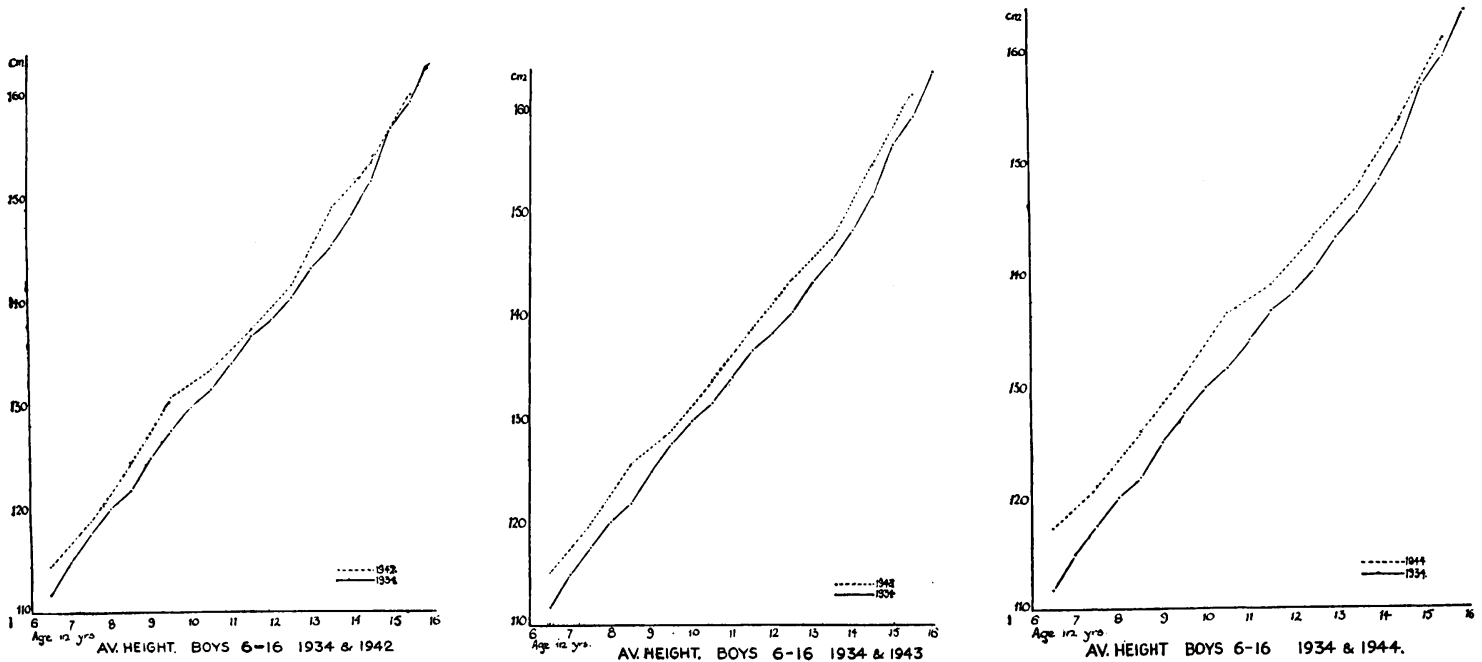

FIG. 2, 3 and 4. Average height for age of boys in 1942, 1943 and 1944 respectively (broken line) compared. with 1934 (unbroken line) in each instance.

or other organizations, it had been possible for selected children, or even the whole colony, to receive double rations through the Secours d'Hiver. In others again the children had received no more, and sometimes less, than the official rations at any period.

Height and weight records were obtained from a residential convent school in an industrial area where the children had received little more than the official rations at any time. The following graphs show the average height and weight of ten girls who had been resident throughout the war. They were all aged $7+$ to 8 in 1939 . The growth curves (broken line) are compared with the 1934 curves (unbroken line) for girls of the same ages (fig. 14 and 15).

These figures show clearly that whereas both height and weight in 1939 were above the 1934 figures, there is a steady falling-off from 1941-2. This is in marked contrast to the Anderlecht figures for children living at home.

Growth of adolescents and the establishment of puberty. Reference has already been made to the probable effect on growth of a delay in the establishment of puberty. Martin (1944) found a marked retardation of puberty in 16.4 per cent. of a group of 250 debilitated adolescents of both sexes under the care of the Foyers Leopold III, but as no detailed records could be obtained for girls, and none at all for sexual development in boys, during the occupation or after the liberation, it has not been possible to correlate the growth curves with the onset of puberty.

If, however, the weight curves of girls aged 11 to 16 for 1942,1943 and 1944 are plotted together, a striking feature emerges (fig. 16). It will be seen that in 1942 a sudden increase in weight occurs between $14 \frac{1}{2}$ and $15 \frac{1}{2}$. In 1943 a similar increase occurs between $13 \frac{1}{2}$ and $14 \frac{1}{2}$, and in 1944 between $12 \frac{1}{2}$ and 131. Although the number of children in each of the 15-to 16-year-old groups is small, the average weights are almost identical. The sudden increase in weight seen in each of the three curves is presumably that normally associated with the onset of puberty, and if this is the case the curves indicate a
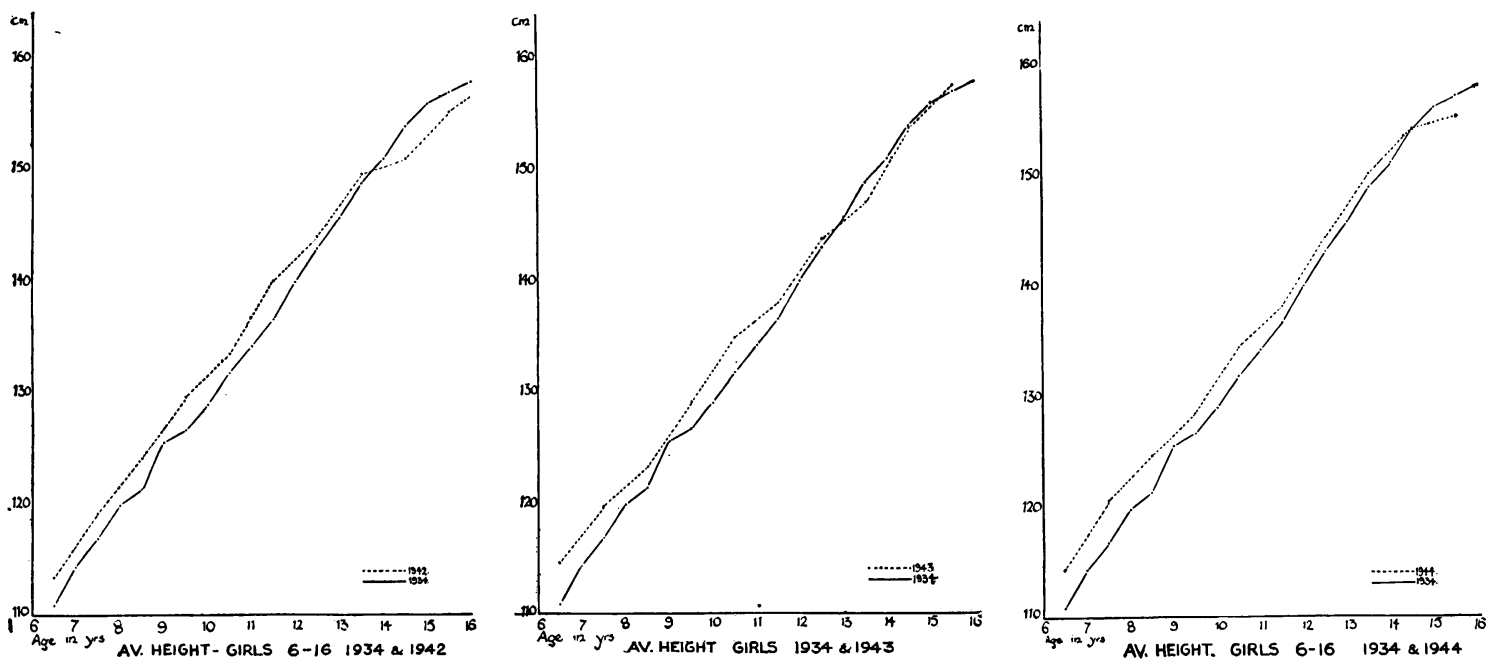

FIG. 5, 6 and 7.-Average height for age of girls in 1942, 1943 and 1944 respectively (broken line) compared with 1934 (unbroken line) in each instance. 

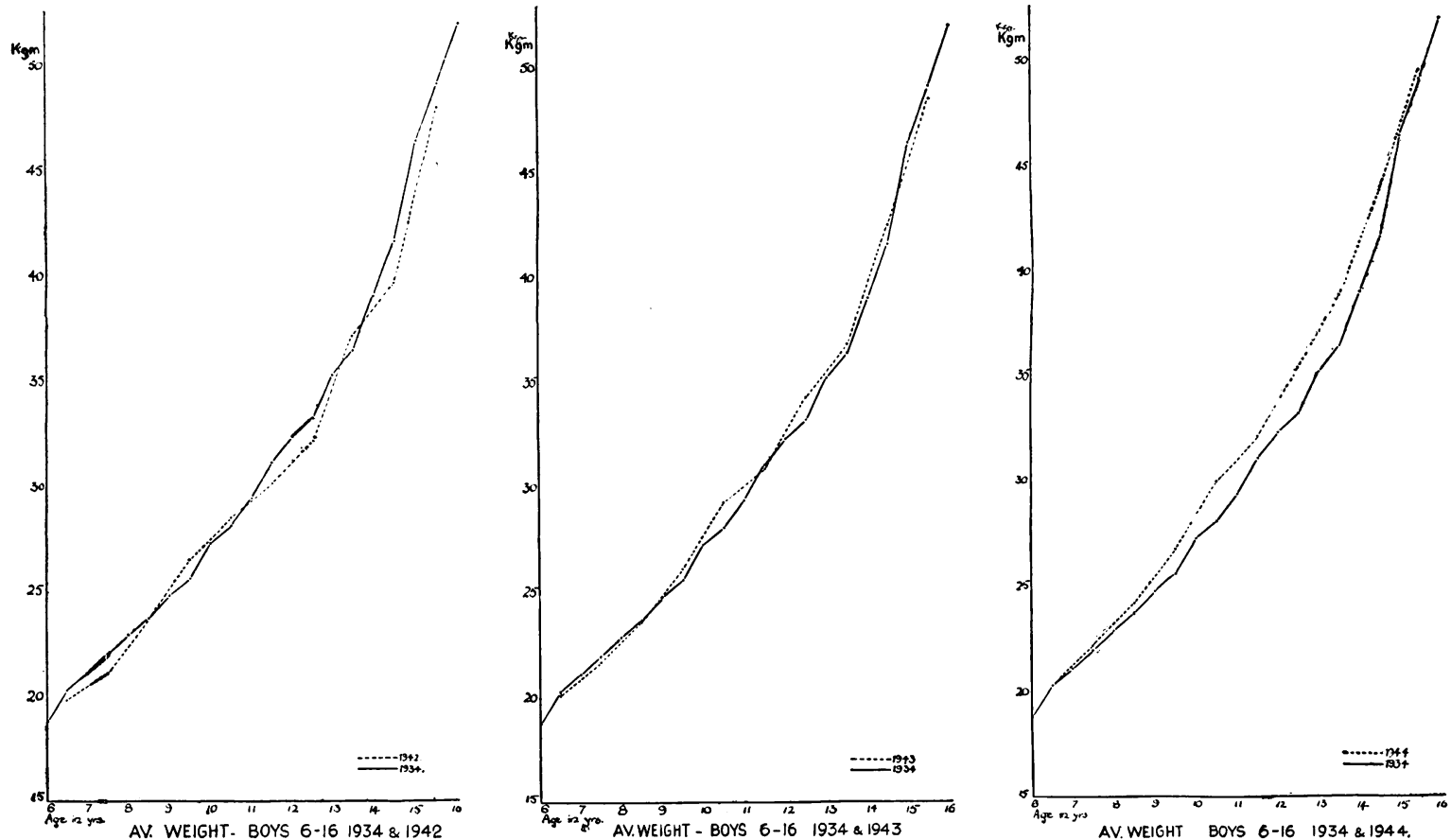

FIG. 8, 9 and 10.-Average weight for age of boys in 1942, 1943 and 1944 respectively (broken line) compared with 1934 (unbroken line) in each instance.
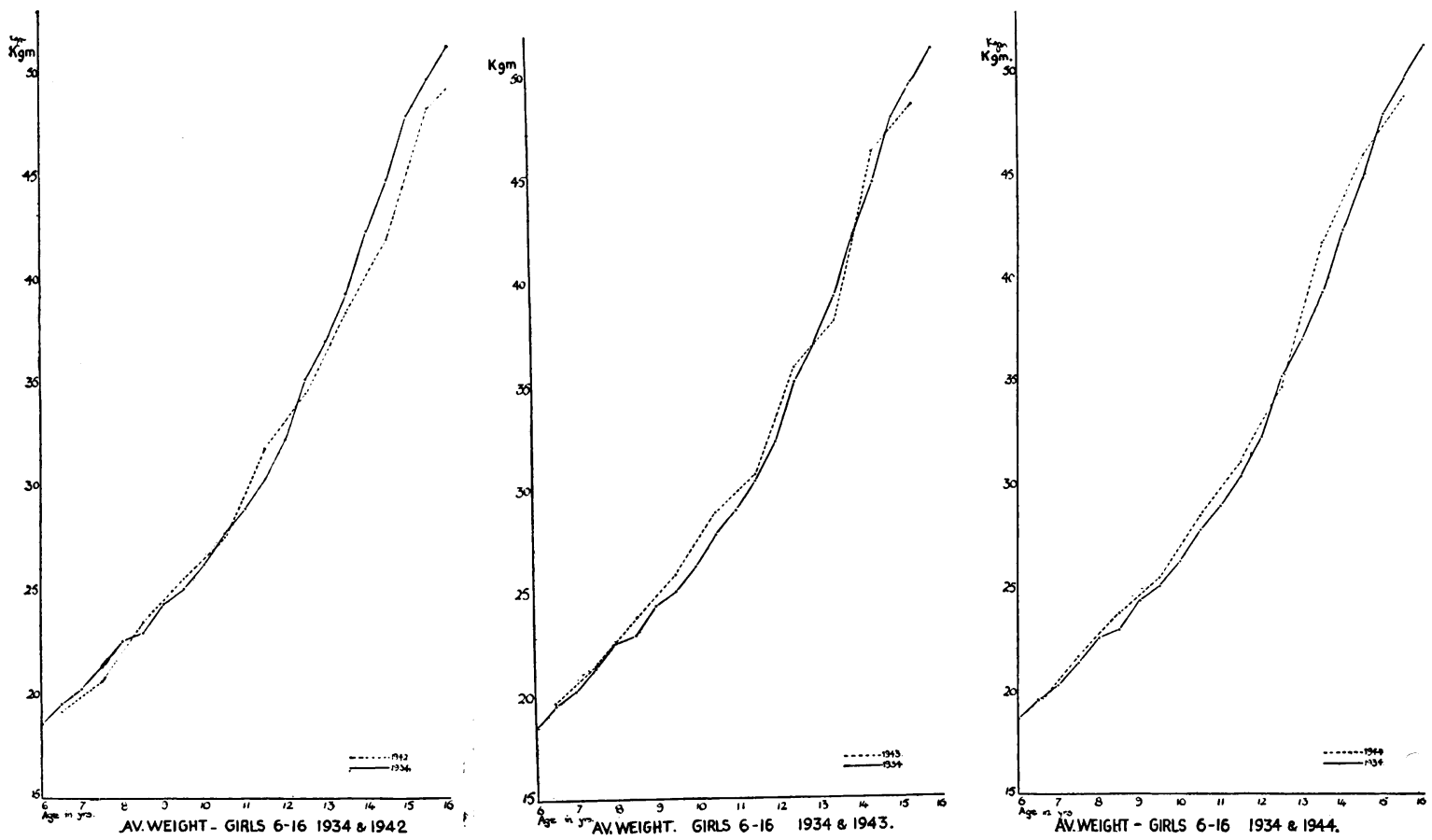

FIG. 11, 12 and 13.-Average weight for age of girls in 1942, 1943 and 1944 respectively (broken line) compared with 1934 (unbroken line) in each instance.

marked delay in 1942 (following the severest period of rationing), a moderate delay in 1943, and an approximately normal onset of puberty in 1944 .

In order to determine whether any delay in the onset of puberty could be demonstrated in February, 1945, or retrospectively, 42 girls aged twelve to twenty in two orphanages, and a group of sixty- four ' normal' schoolgirls aged fifteen to seventeen attending consecutively for school medical examinations, were examined and histories taken. The results are reported separately, as the two orphanages were particularly well cared for, and the adolescents probably better fed than the schoolgirls living at home. 


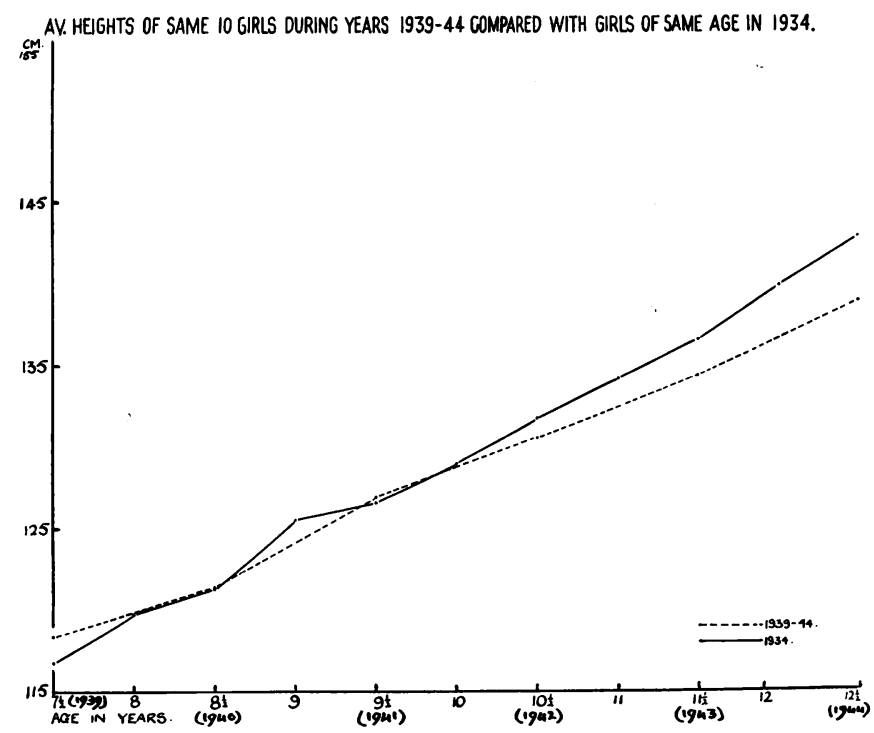

FIG. 14.-Average height of 10 girls aged 7-8 in 1939, from 1939 to 1944 (broken line), compared with 1934 standard (unbroken line).

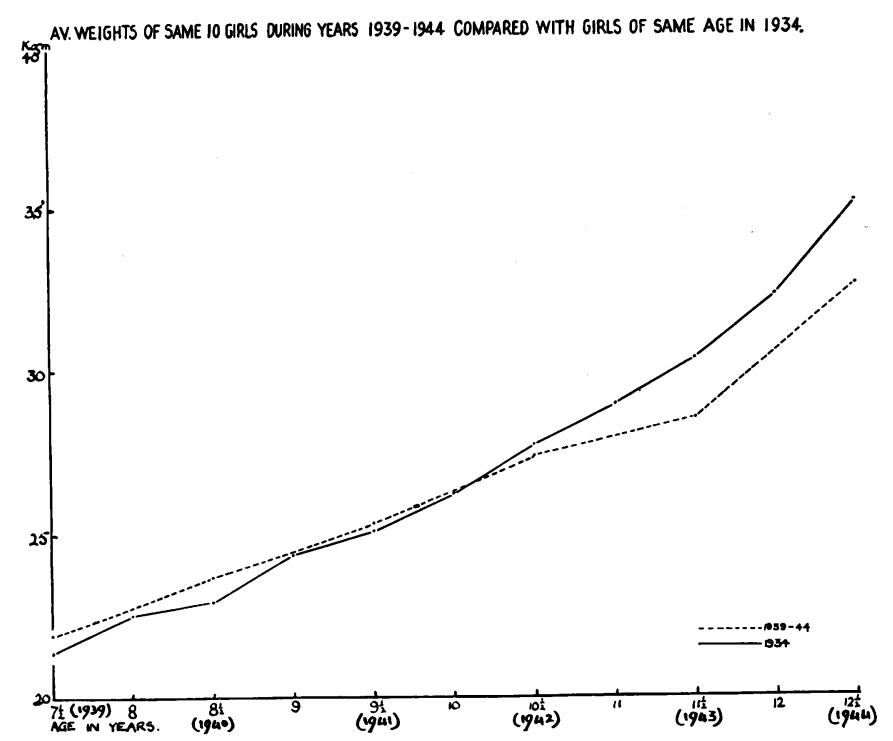

FIG. 15.-Average weight of the same from 1939 to 1944 (broken line) compared with 1934 standard.

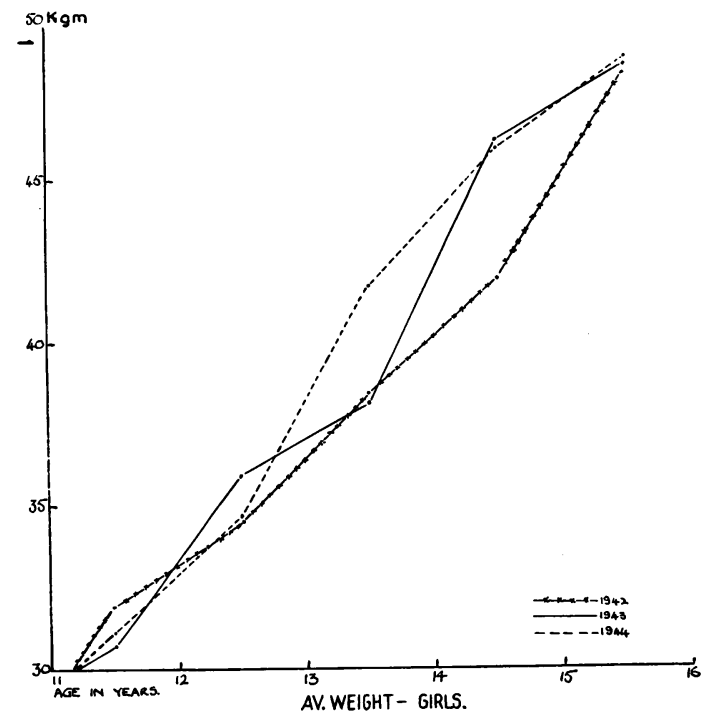

FIG. 16.-Average weights of girls aged 11 to 16 in 1942, 1943 and 1944. 
EXAMINATION OF 42 GIRLS AGED 12 TO 20

\begin{tabular}{|c|c|c|c|c|c|}
\hline AGE (years) & $\begin{array}{l}12+ \\
\text { to } \\
13\end{array}$ & $\begin{array}{l}13+ \\
\text { to } \\
14\end{array}$ & $\begin{array}{l}14+ \\
\text { to } \\
15\end{array}$ & $\begin{array}{l}15+ \\
\text { to } \\
16\end{array}$ & $\begin{array}{l}16+ \\
\text { and } \\
\text { over }\end{array}$ \\
\hline 1. No signs of puberty & 3 & 0 & 0 & 1 & 0 \\
\hline $\begin{array}{l}\text { 2. Early breast develop- } \\
\text { ment and/or pubic hair } \\
\text { without menses }\end{array}$ & 9 & 4 & 7 & 1 & 0 \\
\hline $\begin{array}{l}\text { 3. Menstruation estab- } \\
\text { lished .. }\end{array}$ & 1 & 1 & 3 & 7 & 8 \\
\hline
\end{tabular}

Of the twenty girls who had already menstruated, the first period occurred as follows: 11 to 12 years in two, 12 to 13 years in three, 13 to 14 years in four, 14 to 15 years in six, 15 to 16 years in four, and at 17 years in one. In the absence of any clearly defined standards of the normal age of puberty, it is impossible to speak with precision, but two out of this group (the girl aged $15+$ who showed no evidence of puberty and the girl in whom menstruation was only established at the age of 17) may be taken as showing marked delay, and the five girls in whom menstruation had not occurred before the age of 15 as showing slight delay. In the case of nine girls aged 14 to 15 who had not yet menstruated it is not possible to speak with certainty.

In the group of sixty-four schoolgirls, Dr. W. de Meuter kindly obtained particulars of age of onset of menstruation, and regularity and character of the periods. Of the total sixty-four, eight girls (12.5 per cent.) had not menstruated; these were all aged 15 to 16 years. A further three had menstruated at least once, but had had amenorrhoea for several months at the time of the examination (February, 1945). Of these eleven cases, three showed anaemia of chlorotic type and six obesity and acrocyanosis. Of the fifty-six in which menstruation had occurred, forty had menstruated regularly (discounting irregularities of less than a week from the normal cycle); thirty-seven of these were classified as normal (58 per cent. of total), three showing dysmenorrhoea. In the remaining sixteen, menstruation was or had been grossly irregular, excessive and frequent in three and infrequent in thirteen.

In the fifty-six who had menstruated, the first period had occurred at the following ages: 10 to 11 years in four, 11 to 12 years in four, 12 to 13 years in six, 13 to 14 years in thirteen, 14 to 15 years in twenty-five, and 15 to 16 years in four.

It is considered that the occurrence of complete or prolonged amenorrhoea in 17 per cent. of a group of 'normal' girls over fifteen years of age; irregular and scanty menstruation in a further 20 per cent.; and the occurrence of the first period after the age of fourteen in 52 per cent. of those who had menstruated, must be taken together as definite evidence of delay in the establishment of puberty.

With regard to adolescent boys, it appeared impossible to determine retrospectively the age of onset of puberty. Examination of forty boys aged thirteen to seventeen in the same two orphanages in January, 1945, gave the following results:
EXAMINATION OF 40 BOYS AGED 13 TO 17

\begin{tabular}{|c|c|c|c|c|}
\hline AGE (years) & $\begin{array}{c}13+ \\
\text { to } \\
14\end{array}$ & $\begin{array}{c}14+ \\
\text { to } \\
15\end{array}$ & $\begin{array}{c}15+ \\
\text { to } \\
16\end{array}$ & $\begin{array}{c}16+ \\
\text { to } \\
17\end{array}$ \\
\hline 1. No signs of puberty & 6 & 3 & 0 & 0 \\
\hline $\begin{array}{l}\text { 2. Pubic hair and/or genital } \\
\text { development beginning } \ldots\end{array}$ & 6 & - & - & - \\
\hline $\begin{array}{l}\text { 3. Pubic and body hair plus } \\
\text { genital development }\end{array}$ & 3 & 5 & 6 & 5 \\
\hline
\end{tabular}

From this it is seen that all boys over fifteen have reached full puberty, and if the fourteen- to -fifteenyear age-group is taken as the one in which puberty should normally be appearing, it is found that eleven out of the fourteen boys of this age show puberty beginning or fully established. It is not therefore considered that this particular group of forty boys showed evidence of delay in puberty at the time of the examination. Again, however, the group must be regarded as probably better nourished than working-class boys of the same age living at home.

The following height and weight averages have been obtained for boys aged fourteen to nineteen in government employment (telegraph boys). Here it was possible to obtain corresponding figures for the immediate pre-war period (1938-9) and 1944.

TABLe 6

AVERAGE HEIGHT AND WEIGHT OF TELEGRAPH BOYS AGED 14 TO 19 YEARS

\begin{tabular}{|c|c|c|c|c|c|c|}
\hline \multirow{2}{*}{$\begin{array}{c}\mathrm{AGE} \\
\text { (years) }\end{array}$} & \multicolumn{3}{|c|}{$1938-9$} & \multicolumn{3}{|c|}{1944} \\
\hline & No. & $\begin{array}{c}\text { HEIGHT } \\
\text { (cm.) }\end{array}$ & $\begin{array}{r}\text { WEIGHT } \\
\text { (kgm.) }\end{array}$ & NO. & $\begin{array}{c}\text { HEIGHT } \\
\text { (cm.) }\end{array}$ & $\begin{array}{l}\text { WEIGHT } \\
\text { (kgm.) }\end{array}$ \\
\hline $\begin{array}{l}14-15 \\
15-16 \\
16-17 \\
17-18 \\
18-19\end{array}$ & $\begin{array}{l}78 \\
70 \\
85 \\
39 \\
36\end{array}$ & $\begin{array}{l}159 \cdot 5 \\
163.6 \\
166.0 \\
168 \cdot 6 \\
169.7\end{array}$ & $\begin{array}{l}49 \cdot 5 \\
54 \cdot 4 \\
56 \cdot 7 \\
60 \cdot 1 \\
61 \cdot 2\end{array}$ & $\begin{array}{l}56 \\
44 \\
52 \\
30 \\
42\end{array}$ & $\begin{array}{l}155 \cdot 4 \\
161 \cdot 9 \\
165 \cdot 7 \\
167 \cdot 2 \\
170 \cdot 1\end{array}$ & $\begin{array}{l}44 \cdot 2 \\
50 \cdot 1 \\
54 \cdot 0 \\
60 \cdot 1 \\
61 \cdot 1\end{array}$ \\
\hline
\end{tabular}

From these figures (fig. 17 and 18) it is seen that the weight of the boys from $14 \frac{1}{2}$ to $16 \frac{1}{2}$ is substantially lower in 1944 than before the war, but that the two oldest age-groups are practically identical. The height also is lower in the $14 \frac{1}{2}$ and $15 \frac{1}{2}$ groups in 1944 , but approaches the pre-war figures in the $16 \frac{1}{2}$ group and is slightly higher in the $18 \frac{1}{2}$ group. It is possible that the large difference in the younger agegroups might be partly accounted for by a delay in the onset of puberty, but it must be remembered that the oldest boys had all been four to five years in government employment and their normality cannot necessarily be taken as typical of the population as a whole at this age. It is noteworthy that the 1944 figures for the boys of fourteen to sixteen correspond fairly closely to the figures for Anderlecht schoolboys of the same age in 1944 . It is therefore additionally probable that the Anderlecht 


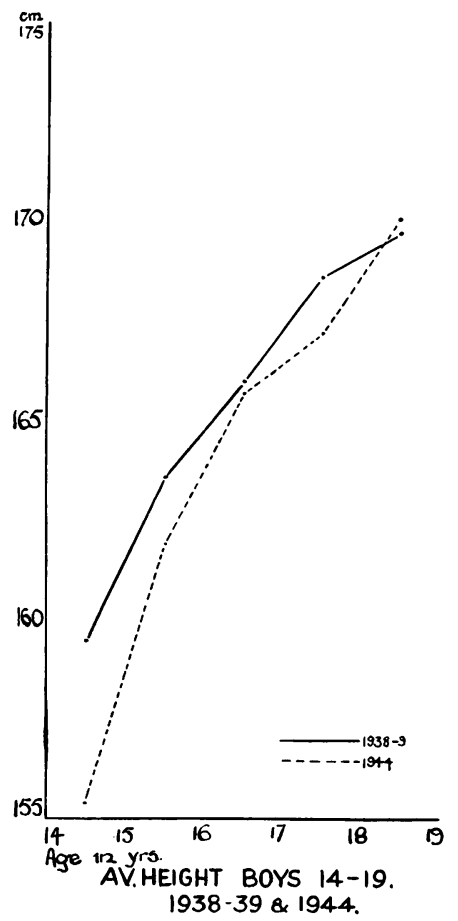

FIG. 17.-Average height of telegraph boys aged 14 to 19 in 1938-9 compared with 1944.

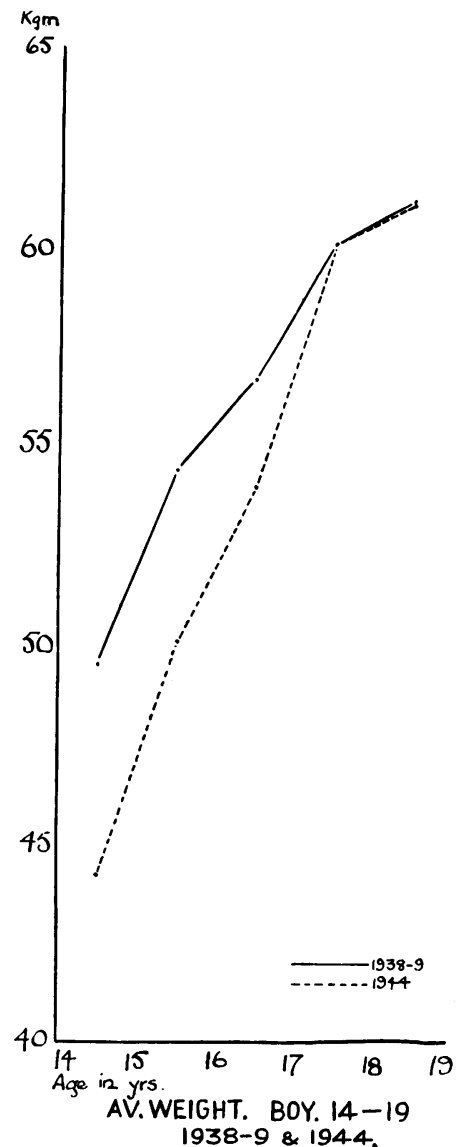

Fig. 18.-Average weight of the same boys as in fig. 17 figures are still well below the 1939 normal for boys of this age although they compare favourably with the figures published in 1934

The effect of supplements in 1941 and 1943. The deficiency of the war diet in fat and animal protein, and the utilization of supplements, are well illustrated by the following two natural experiments which were extracted from the records of the Orphelinat Rationaliste, Brussels, by courtesy of the directors, M. and Mme. Lhoir. This is a small orphanage containing in the first experiment thirty-four children (seventeen boys and seventeen girls, between four and eighteen years of age) and in the second thirty-one children (fourteen girls and and seventeen boys, between five and seventeen years). The children appear to have been exceptionally well cared for, and during the period of the first experiment (March to May, 1941) were receiving double rations of butter and margarine (500 gm. of each per month instead of $250 \mathrm{gm}$.) $2 \mathrm{kgm}$. per month of sugar instead of $1 \mathrm{kgm}$., and $350 \mathrm{gm}$. of bread per day instead of $250 \mathrm{gm}$.

EXPERIMENT 1. The children were weighed on 1.3.41 and again on 15.3.41. All except four had lost weight during this period, the aggregate alteration in weight of the whole group being a loss of $10.4 \mathrm{kgm}$. On 15.3.41 a calf was killed, giving a supplement of $40 \mathrm{kgm}$. veal which was consumed between 15.3.41 and 25.3.41. On 1.4.41 the children were re-weighed, when it was found that all except two had gained weight, the aggregate alteration in weight being a gain of $35.5 \mathrm{kgm}$. After a further month on the previous rations, the children were re-weighed on 1.5.41, when all but one had lost weight again, the aggregate being a loss of $38.9 \mathrm{kgm}$. In other words, the immediate gain in weight represented seven-eighths of the weight of the supplement supplied, all of which was rapidly lost again on return to the restricted rations.

EXPERIMENT 2. The second experiment was carried out in December, 1943, to March, 1944, when the children were receiving the supplementary rations accorded to debilitated children by the Oeuvre Nationale de l'Enfance, namely, a variable supplement of sardines and condensed milk, and double rations of bread, jam, potatoes, with a triple ration of milk ( 24 litres a month).

The children were weighed on 1.11 .43 and on 1.12.43, when the aggregate showed a total gain in weight of $7.4 \mathrm{kgm}$. On December 1 a pig was killed, providing $20 \mathrm{kgm}$. of fresh pork and a corresponding weight of bacon and ham which was consumed over the next six months. Re-weighing on 1.1.44 showed an aggregate gain in weight of $21.8 \mathrm{kgm}$. and on 1.2 .44 a further gain of $25 \mathrm{kgm}$. In February a second pig was killed, providing approximately the same supplement and re-weighing on 1.3.44 showed an aggregate gain of $15.6 \mathrm{kgm}$.

Although this experiment is not as controlled as the previous one (since a supplement of bacon and ham was consumed during January), it shows that when a supplement was given on more adequate rations, a large proportion of the weight of the supplement again appeared as additional gain in weight of the children, and that in this case the gain was not only maintained but continued into the subsequent month. After two months' rapid gain in weight, however, the children did not show as big a weight-response to the second pig as they did to the first, although the aggregate gain in weight 
during the month was still double that occurring in the month before the experiment was started.

\section{Summary and conclusions}

1. A brief outline is given of nutritional conditions in Belgium during the occupation and up to February, 1945, and the principal means by which children had been protected against the worst effects of malnutrition. The safeguarding of the younger age-groups represents a long-sighted policy which was adopted from the beginning of the occupation, and reflects the greatest credit on those responsible for the welfare of children in Belgium.

2. The general health of children during the war is discussed. With the exception of rickets, deficiency diseases do not appear to have been of exceptionally high incidence, but there is thought to have been a considerable increase in osteomyelitis associated with skin sepsis.

3. A detailed study of a working-class urban family with three children is given, and the weekly budget in February, 1945, discussed.

4. Height and weight curves of children living in a working-class urban commune are presented for 1942, 1943 and 1944. Whilst there has been a steady and substantial improvement since 1942, there is evidence that the average values in the autumn of 1944 were still substantially below those for 1939 . This was clearly seen in boys in employment aged fourteen to sixteen.

5. Adolescents appear to have suffered more than the younger age groups and a study of 106 adolescent girls indicates a retardation of puberty in a significant proportion of those living at home in a working-class commune.

6. It is considered that in the winter of 1944-5, Belgian children as a whole were suffering more from lack of fuel, warm clothes, and soap than from lack of calories, although the food situation was still unsatisfactory.

Thanks are due to Air-Marshal Sir Harold Wittingham, K.C.B., D.G.M.S., R.A.F., for permission to publish this report; Dr. Goossens, Director-General, Ministère de Santé Publique; members of the F.A.U. who assisted in the collection of material; Dr. Heymans, Médecin-en-chef, Dr. W. de Meuter, and Mme. Denis, Infirmière-enchef, Clinique Scolaire, Anderlecht; and other Belgian colleagues and friends for their cooperation. Thanks are also due to L.A.C. Cresswell for much technical assistance in the preparation of the graphs.

\section{REFERENCES}

Association des caisses d'allocations familiales (1942). Enquête sur l'état sanitaire de l'enfance, quoted by Colard, loc. cit.

Bastenie, P., and others (1944). Rapport sur l'Etat Sanitaire de la Population Bruxelloise pendant les periodes de Restrictions Alimentaires (1940-1944), Brussels, privately published.

Colard, J. (1945). L'Alimentation de la Belgique sous l'Occupation Allemande 1940-1944, Louvain.

Dubois, R. (1945). Personal communication.

Ellis, R. W. B. (1945). Proc. roy. Soc. Med., 38, 449.

Garot, L. (1945). Enquête sur l'état de santé des enfants Belges des regions industrielles. Belgian-American Educational Foundation Inc., privately published.

Gregoire, P. E. (1942). Rapport du Secours d'Hiver, quoted by Bastenie, loc. cit.

Henry, G. (1945). Personal communications.

Jacquemijns, G. (1941), quoted by Colard, loc cit.

Lust, M. (1942). Arch.Méd. Belges, 3, 1 .

Martin, L. (1944), quoted by Bastenie, loc. cit.

Ministére de l'Instruction Publique (1934). Valeurs moyennes, evaluées en semestres, de la Taille et du Poids de l'enfant belge entre 3 et 18 ans, Brussels.

Snoeck, J. (1942). Rapport du Secours d'Hiver, quoted by Bastenie, loc. cit. 